\title{
Heavy Metals (Cu, Fe, Ni and Zn) in Traditional Chinese Herbal Medicines Bought from Selected Shops from Peninsular Malaysia
}

\author{
Chee Kong Yap", Nurelly Mohd Rihan1, Wan Hee Cheng², Rosimah \\ Nulit' ${ }^{1}$, Salman Abdo Al-Shami ${ }^{3}$ and Wickneswari Ratnam ${ }^{4,5}$ \\ 1Department of Biology, Faculty of Science, Universiti Putra Malaysia, 43400 UPM, \\ Serdang, Selangor, Malaysia
}

2Inti International University, Persiaran Perdana BBN, Nilai, Negeri Sembilan, Malaysia

${ }^{3}$ Biology Department, University College of Taymma, University of Tabuk, Taymma, Tabuk, Saudi Arabia

${ }^{4}$ Nomatech Sdn Bhd (935220-W), Lot 1282, Jalan Besar, Kampung Batu 27, 43700 Beranang, Selangor, Malaysia

${ }^{5}$ Faculty of Science and Technology, Universiti Kebangsaan Malaysia, 43600 Bangi, Selangor, Malaysia

*Corresponding author: Chee Kong Yap ,Department of Biology, Faculty of Science, Universiti Putra Malaysia, 43400 UPM, Serdang, Selangor Malaysia, Email: yapckong@hotmail.com

\section{Abstract}

A total of 20 Traditional Chinese Herbal Medicine (TCHM) was bought randomly from shops in three states of Peninsular Malaysia. All of these samples were analyzed for $\mathrm{Cu}, \mathrm{Fe}, \mathrm{Ni}$ and $\mathrm{Zn}$ concentrations. Based on samples collected from selected shops in Peninsular Malaysia, the levels of $\mathrm{Cu}, \mathrm{Fe}, \mathrm{Ni}$ and $\mathrm{Zn}$ in the TCHM samples were comparable to reported studies of TCHM products in the literature. The levels of essential Fe and Zn were found to be higher than the levels of the essential $\mathrm{Ni}$ and $\mathrm{Cu}$. The present levels of the 20 TCHM products from Malaysia can serve as important baseline information for future reference in the establishment of MRLs of the four less common heavy metals in Malaysia as well as in this region. Therefore, it is difficult to conclude whether the TCHM products are safe from contamination of $\mathrm{Cu}$, Fe, $\mathrm{Ni}$ and $\mathrm{Zn}$ since the MRLs for $\mathrm{Cu}, \mathrm{Fe}, \mathrm{Ni}$ and $\mathrm{Zn}$ have not been recommended by WHO. Future regular monitoring, quality control and adequate regulatory measures of TCHM products for heavy metals are necessary.

Keywords: Heavy metals; Traditional Chinese Herbal Medicines; Malaysia

\section{Introduction}

Tradition Chinese Herbal Medicines (TCHMs) are currently used by large sections of the population. Because they are not regulated as medicines and are freely available to everyone, serious safety concerns might be associated with these Herbal Medicines (HMs) [1]. According to Rao and Galib (2011) [2], WHO has emphasized the need for quality assurance of herbal products, including testing of heavy metals? Ernest (2002) concluded from a review paper that evidence suggesting that some Asian HMs containing toxic heavy metals or undeclared prescription drugs. Evidence from various countries implies that toxic heavy metals and undeclared prescription drugs in Asian HMs might constitute a serious health problem. However, the 
majority of the data is anecdotal and insufficient to define prevalence figures. Ways ought to be found to maximize consumer safety.

According to Donkin, et al. the common industrial uses of $\mathrm{Ni}$ are coins, jewellery, alloy, plating and batteries while the principal toxic effect is dermatitis in human. For Zn, the common industrial uses are batteries, alloys, galvanizing, dyes, and pharmaceuticals batteries while the principal toxic effects are gastrointestinal effects and anemia in human, According to Chan, et al. (1993) [3], the regulation of heavy metal contents in TCHM products has been an international concern. The increasing incidence of severe and fatal metal poisoning in the public has somewhat tarnished the overall image of TCHM products. Therefore, there is a need to screen the heavy metal levels in the TCHM in Malaysia since these TCHM products that is available in the market are imported where the safety consumption of these products were generally unknown. The safety issue of TCHM is an essential scientific subject of interest Ernst (1999) [4] which revolve the potential toxicity, risk and benefit of the TCHM product [5]. Many studies can be found in the literature regarding the toxic $\mathrm{Hg}, \mathrm{Cd}$ and $\mathrm{Pb}$ levels in $\mathrm{HMs}$ but less in number for $\mathrm{Cu}, \mathrm{Fe}$, $\mathrm{Ni}$ and $\mathrm{Zn}$. However, there is a growing concern on the levels of $\mathrm{Cu}, \mathrm{Fe}, \mathrm{Ni}$ and $\mathrm{Zn}$ in the TCHM products/ For example, Wang, et al. (1999) [6] analyzed four heavy metals including $\mathrm{Ni}$ and $\mathrm{Zn}$ in seven TCHM products purchased locally.

We previously reported the toxic $\mathrm{Cd}$ and $\mathrm{Pb}$ contents in the TCHM sold in Malaysian markets [7] but the levels of $\mathrm{Cu}, \mathrm{Fe}, \mathrm{Ni}$ and $\mathrm{Zn}$ have not been published. Therefore, the objective of the present study was to determine the background concentrations of $\mathrm{Cu}, \mathrm{Fe}, \mathrm{Ni}$ and $\mathrm{Zn}$ in the TCHM products sold from several markets in Kuala Lumpur, Selangor and Johore, from Peninsular Malaysia.

\section{Materials and Methods}

A total of 20 TCHM samples of different therapeutic effects were bought from several markets in Kuala Lumpur, Selangor and Johore between April and July 2005. All the samples were randomly purchased and selected. All these TCHM products are commonly used by many Malaysians. Samples bought were taken back to the laboratory and stored at room temperature. Ingredients and medicinal properties for the collected samples are presented in Table 1 [7].

\begin{tabular}{|c|c|c|c|}
\hline No. & Name of product/ samples & Ingredients & Medicinal properties \\
\hline 1 & Herbal tea & Tea leaves, radix and Mentha arvensis & Sore throat, headache and fatigue \\
\hline 2 & Ginseng Pills & American ginseng & Fatigue and blood pressure \\
\hline 3 & Ban Kah Chai & Pepermint oil and pogostemonis & Stomachache and diarrhea \\
\hline 4 & Li Chee Powder & Pulsatilla chinensis and Paenial actiflord & Mild diarrhea \\
\hline 5 & Green Pills & Cordyceps sinensis & Fever \\
\hline 6 & Bo Ji Wan & Essential oil and radix & Diarrhea and flu \\
\hline 7 & Chee Ke Wan & Radix and gypsum & Throat ulcer \\
\hline 8 & Chee Suat Tan & Radix and essential oil & Cough \\
\hline 9 & Seng Lian Cough Pills & Essential oil and radix & Fever \\
\hline 10 & Intamol & Bark of "Guan Ying Chian" & Fatigue and blood pressure \\
\hline 11 & Guan Ying Chian & Bark of "Pang Nian Jin" & Fatigue and relief cold \\
\hline 12 & Pang Nian Jin & Rhizome Belancandae and essential oil & Cold relief \\
\hline 13 & Cold Relief Pills & Essential oil & Flu \\
\hline 14 & Flu Pills & Artemisia, malt and coptis & Woman stomachache \\
\hline 15 & Biau Leng San & Mentha herb and radix angelica & Improving appetite \\
\hline 16 & Dh Ouh Pau Chee San Medicated Powden & Merb and radix angelica & Stomachache and flatulence \\
\hline 17 & Stomachache Powder & Essential oil and rhizome cymbopogon & Indigestion and vomiting \\
\hline 18 & Soo Hup Wan Tiny Pills & Poriacocos and semen Plantago asiatico & Stomachache \\
\hline 19 & Tou Seah San (Baby) & Essential oil and ginseng & Reducing heat \\
\hline 20 & Hung Lien Shang Ching Pien & . & \\
\hline
\end{tabular}

Table 1: Chinese Herbal Medicines under investigation; name, ingredients and medicinal properties. Note: Information is gathered from the label of each Chinese Herbal Medicines [7]. 
The samples were cleaned and removed of any particulates that came with the herbal were removed. Samples were then dried at $105^{\circ} \mathrm{C}$ for least $16 \mathrm{~h}$ until constant dry weight was achieved. Dried samples were shaken vigorously through a $0.5 \mathrm{~mm}$ stainless steel sieve to achieve homogeneity. Three replicates of each TCHM sample were analyzed for $\mathrm{Cd}$ and $\mathrm{Pb}$.

Extraction of heavy metals from TCHM samples was performed by using the acid digestion method. Dried TCHM samples (1 gram each) were digested in a combination of concentrated nitric acid (69\%) and perchloric acid $(60 \%)$ at $4: 1$ ratio, at $40^{\circ} \mathrm{C}$ for the first hour and $140^{\circ} \mathrm{C}$ for the next 3 hours.

Digested samples were then diluted with double distilled water and filtered through Whatman No.1 filter paper before they were stored for metal determination later on. Determination of $\mathrm{Cu}, \mathrm{Fe}, \mathrm{Ni}$ and $\mathrm{Zn}$ in the digested samples was carried out by using an Atomic Absorption
Spectrophotometer (AAS) Model AAnalyst 800. For quality control, all glass wares used were acid-washed to avoid contamination. In addition to that, the procedural blanks were analyzed together with the samples. The data from the AAS were verified by certified reference materials (IAEA Soil-5) and the recoveries for the two metals were of satisfactory (80-120\%).

\section{Results and Discussion}

\section{Fe}

Fe levels ranged from 0.70 to $1873 \mathrm{mg} / \mathrm{kg}$ dry weight $(\mathrm{dw})$ (Table 2) with the highest Fe level was found in Bo Ji Wan while Soo Hup Wan Tiny Pills, Biau Leng San, and Cold Relief Pills also exceeded 1000. However, maximum permissible/residue limits for $\mathrm{Fe}$ in herbal products have yet to be set at the global level [8], as reviewed by Sarma, et al. (2011) [9]. WHO does not recommend any maximum residue limit (MRL) for Fe [10].

\begin{tabular}{|c|c|c|c|c|}
\hline Medicines & $\mathbf{C u}$ & $\mathbf{F e}$ & $\mathbf{N i}$ & $\mathbf{Z n}$ \\
\hline Herbal Tea & $12.20 \pm 5.76$ & $660 \pm 395$ & $23.6 \pm 36.4$ & $35.4 \pm 18.2$ \\
\hline Ginseng Pills & $3.04 \pm 0.88$ & $32.7 \pm 3.05$ & $0.97 \pm 0.49$ & $1.86 \pm 0.54$ \\
\hline Ban Kah Chai & $13.1 \pm 1.81$ & $579 \pm 39.2$ & $3.07 \pm 0.77$ & $63.7 \pm 4.65$ \\
\hline Li Chee Powder & $8.29 \pm 0.62$ & $384 \pm 20.8$ & $2.63 \pm 1.22$ & $25.7 \pm 1.59$ \\
\hline Green Pills & $3.42 \pm 0.34$ & $17.5 \pm 5.81$ & BDL & $1.25 \pm 0.51$ \\
\hline Bo Ji Wan & $9.39 \pm 0.25$ & $1873 \pm 57.8$ & BDL & $27.3 \pm 1.86$ \\
\hline Chee Ke Wan & $8.14 \pm 0.65$ & $668 \pm 66.9$ & $1.45 \pm 1.31$ & $31.8 \pm 2.45$ \\
\hline Chee Suat Tan & $13.1 \pm 1.81$ & $579 \pm 39.2$ & $3.07 \pm 0.77$ & $63.7 \pm 4.65$ \\
\hline Seng Lian Cough Pills & $8.07 \pm 0.49$ & $203 \pm 66.9$ & $12.1 \pm 0.77$ & $47.0 \pm 1.32$ \\
\hline Intamol & BDL & $35.7 \pm 25.2$ & $0.95 \pm 0.52$ & $0.03 \pm 0.73$ \\
\hline Guan Ying Chian & $4.11 \pm 0.45$ & $0.70 \pm 0.21$ & $54.5 \pm 165$ & $13.2 \pm 3.05$ \\
\hline Pang Nian Jin & $1.60 \pm 0.53$ & $41.7 \pm 8.88$ & $0.93 \pm 0.34$ & $3.36 \pm 0.09$ \\
\hline Cold Relief Pills & $6.56 \pm 0.16$ & $1041 \pm 35.8$ & $12.2 \pm 1.00$ & $20.0 \pm 0.47$ \\
\hline Flu Pills & $0.22 \pm 0.19$ & $45.9 \pm 9.73$ & $2.96 \pm 0.53$ & $1.53 \pm 0.67$ \\
\hline Biau Leng San & $22.2 \pm 3.78$ & $1026 \pm 25.0$ & $12.9 \pm 9.13$ & $61.2 \pm 6.52$ \\
\hline Chee San Medicated Powder & $9.77 \pm 2.26$ & $449 \pm 23.6$ & $6.01 \pm 0.34$ & $78.1 \pm 6.91$ \\
\hline Stomachache Powder & $5.21 \pm 1.04$ & $189 \pm 9.50$ & $1.87 \pm 0.21$ & $21.1 \pm 1.50$ \\
\hline Soo Hup Wan Tiny Pills & $8.68 \pm 0.71$ & $1115 \pm 52.1$ & $8.89 \pm 1.31$ & $35.6 \pm 4.89$ \\
\hline Tou Seah San (Baby) & $1.35 \pm 1.07$ & $108 \pm 7.00$ & $8.77 \pm 0.77$ & $16.7 \pm 1.85$ \\
\hline Hung Lien Shang Ching Pien & $6.30 \pm 1.60$ & $245 \pm 22.7$ & $3.74 \pm 0.93$ & $22.3 \pm 1.13$ \\
\hline Min & BDL & 0.70 & BDL & 0.03 \\
\hline Max & 22.2 & 1873 & 54.5 & 78.1 \\
\hline
\end{tabular}

Table 2: Concentrations (mean \pm standard error, $\mathrm{mg} / \mathrm{kg}$ dry weight) of $\mathrm{Cu}, \mathrm{Fe}, \mathrm{Ni}$ and $\mathrm{Zn}$ in the Chinese tradition herbal medicines bought from selected shops in Peninsular Malaysia.

$\mathrm{BDL}=$ Below Detection Limit

The present levels are relatively high when compared to $\mathrm{Fe}$ in most medicinal plants for the treatment of anemia. Nkansah, et al. (2016) [11] reported the mean Fe concentration of the 15 medicinal plant samples from 


\section{Food Science and Nutrition Technology}

Kumasi (Ghana) was $4.66 \mathrm{mg} / \mathrm{kg}$, ranging from 2.51 to $7.06 \mathrm{mg} / \mathrm{kg}$. Dghaim, et al. (2015) [12] reported that the Fe concentrations in the in selected traditional herb sconsumedin the United Arab Emirates (UAE), purchased from the local market in Dubai were81.3 $1101 \mathrm{mg} / \mathrm{kg}$. Konieczyński, et al. (2007) [13] reported that Fe levels in selected medical herbs known for the treatment of anemia in Poland, ranged from 6.67 to 223 $\mathrm{mg} / \mathrm{kg} \mathrm{dw}$.

Zhu, et al. (2013) [14] reported the concentrations of $\mathrm{Fe}$ in the dried herbal flowers from China were in the range of $312-1.389 \mathrm{mg} / \mathrm{kg} \mathrm{dw}$. The present herbal tea (based on the leaves) from the present study was found to be $660 \mathrm{mg} / \mathrm{kg} \mathrm{dw}$ for Fe. Nkuba and Mohammed (2017) [15] reported the concentrations of $\mathrm{Fe}$ in analyzed medicinal plants ranged from $89.02-553.46 \mathrm{mg} / \mathrm{kg}$, $246.44-572.81 \mathrm{mg} / \mathrm{kg}$ to $380.56-798.43 \mathrm{mg} / \mathrm{kg}$ for leaves and root of Moringa oleifera and in Hibiscus sabsdariffa, respectively.

$\mathrm{Fe}$ is an essential element for human growth and development and an essential component of haemoglobin. It facilitates the oxidation of carbohydrates, proteins and fats to control body weight, which is a very important factor is diabetes management. Iron is necessary for the formation of haemoglobin and also plays an important role in oxygen and electron transfer in the human body. Low iron content causes gastrointestinal infection, nose bleeding and myocardial infection [16].

\section{Zn}

Zn levels ranged from 0.03 to $78.1 \mathrm{mg} / \mathrm{kg} \mathrm{dw}$ (Table 2) with the highest $\mathrm{Zn}$ level was found in Oh Ouh Pau Chee San Medicated Powder. However, maximum permissible/residue limits for $\mathrm{Zn}$ in herbal products have yet to be set at the global level [8], as reviewed by Sarma, et al. (2011) [9]. WHO does not recommend any MRL for Zn [10].

Nkansah, et al. (2016) [11] reported the mean Zn concentration of the 15 medicinal plant samples from Kumasi (Ghana) was $0.53 \mathrm{mg} / \mathrm{kg}$. The highest concentration was recorded in G. kola $(1.07 \mathrm{mg} / \mathrm{kg})$. The present $\mathrm{Zn}$ range is relatively comparable to other studies. For instance, a study on the levels of $\mathrm{Zn}$ in some medicinal plants from India gave concentrations in the range 21.3$48.5 \mathrm{mg} / \mathrm{kg}$ dw [17]. A study in Pakistan also gave $\mathrm{Zn}$ levels slightly above that of this study in the range of below detection - $502 \mathrm{mg} / \mathrm{kg} \mathrm{dw}$ [18]. Dghaim, et al. (2015) [12] reported that the Zn concentrations in the in selected traditional herbs consumed in the United Arab Emirates (UAE), purchased from the local market in Dubai were12.7 -147mg/kg for Zn. Zhu, et al. (2013) [14] reported the concentrations $\mathrm{Zn}$ in the dried herbal flowers from China were in the range of $39.5-97.4 \mathrm{mg} / \mathrm{kg}$ $\mathrm{dw}$. The present herbal tea (based on the leaves) from the present study was found to be 35.4 for Zn. Nkuba and Mohammed (2017) [15] reported the concentrations $(\mathrm{mg} / \mathrm{kg} \mathrm{dw})$ of $\mathrm{Zn}$ in the analyzed plant samples ranged from 8.67 to $23.54,15.51$ to 27.13 and 7.09 - 15.1 in $M$. oleifera leaves, roots and $H$. sabsdariffa, respectively

$\mathrm{Zn}$ is an essential element, playing an important role as a cofactor for more than 100 metalloenzymes and its deficiency can have adverse effects on normal growth and development, reproduction, and immune function. $\mathrm{Zn}$ deficiency may also affect the bone metabolism and gonadal function [19].Nevertheless, at a level higher than the sufficient concentrations, a number of these essential metals is potentially toxic Obi et al., 2006 [20].

\section{$\mathrm{Cu}$}

The $\mathrm{Cu}$ concentrations ranged from BDL to $22.2 \mathrm{mg} / \mathrm{kg}$ $\mathrm{dw}$ (Table 2), with the highest concentration in Biau Leng San (Table 2). It is the only TCHM that exceeded 20.0 $\mathrm{mg} / \mathrm{kg} \mathrm{dw}$ which has become maximum residue limit recommended by Chinese Pharmacopoeia (2015) [21]. The present $\mathrm{Cu}$ ranges are also well below national limit of $150 \mathrm{mg} / \mathrm{kg} \mathrm{dw}$ for finished herbal products set by Singapore [10], but WHO does not recommend any MRL for $\mathrm{Cu}[10]$.

Ting et al. (2013) [22] reported a Cu range of 0.08-0.35 $\mathrm{mg} / \mathrm{kg}$ (based on boiled and non-boiled decoctions) in four commonly consumed TCHMs in Malaysia namely "Eight Treasure Herbal Tea", "Herbal Tea", Xiyang shen (Radix panacis quinquefolii) and Dangshen (Radix codonopsis) ", which were bought randomly from two shops in Kuala Lumpur (but the sampling dates were not specified). Nkuba and Mohammed (2017) [15] reported the concentrations of $\mathrm{Cu}$ varied from $1.58-6.22 \mathrm{mg} / \mathrm{kg}$, $1.20-3.79 \mathrm{mg} / \mathrm{kg}$ and $0-0.42 \mathrm{mg} / \mathrm{kg}$ in M. oleifera leaves, roots and $H$. sabsdariffa, respectively.

Zhu et al. (2013) [14] reported that the highest $\mathrm{Cu}$ content was $15.3 \mathrm{mg} / \mathrm{kg} \mathrm{dw}$ in herbal flowers C. officinalis, whereas the lowest $\mathrm{Cu}$ contentwas $0.826 \mathrm{mg} / \mathrm{kg}$ in herbal flower Rosarugosa, most samples having concentrations between 5.0 and $15.0 \mathrm{mg} / \mathrm{kg}$. The present $\mathrm{Cu}$ levels were in agreement with the literature data [16]. 


\section{Food Science and Nutrition Technology}

\section{$\mathrm{Ni}$}

Ni levels ranged from BDL to $54.5 \mathrm{mg} / \mathrm{kg} \mathrm{dw}$ (Table 2) with the highest Ni level was found in Guan Ying Chian. Zhu et al. (2013) reported that the minimum and maximum $\mathrm{Ni}$ levels observed were $0.189 \mathrm{mg} / \mathrm{kg}$ in Lavandula angustifolia and $18.9 \mathrm{mg} / \mathrm{kg}$ in Chimonanthus praecox. However, maximum permissible/residue limits for $\mathrm{Ni}$ in herbal products have yet to be set at the global level [8], as reviewed by Sarma et al. (2011) [9]. WHO does not recommend any MRL for Ni [10].

The Ni levels were in agreement with those reported in the literature [16]. Nkuba and Mohammed (2017) [15] reported the $\mathrm{Ni}$ levels $(\mathrm{mg} / \mathrm{kg} \mathrm{dw})$ ranging from 0.09 4.89, 0.33-3.08 and 0.98-2.15 in M. oleifera leaves, roots and $H$. sabsdariffa, respectively. Dghaim et al. (2015) [12] reported that the $\mathrm{Cu}$ concentrations in the in selected traditional herbs consumed in the United Arab Emirates (UAE), purchased from the local market in Dubai were: $1.44-156 \mathrm{mg} / \mathrm{kg} \mathrm{dw}$.

The most common ailment arising from $\mathrm{Ni}$ is an allergic dermatitis known as $\mathrm{Ni}$ itch, which usually occurs when the skin is moisture state [23]. Ni has been also identified as carcinogen and adversely affects lungs and nasal cavities [23].

\section{General Discussion}

The present study revealed that levels of $\mathrm{Fe}$ and $\mathrm{Zn}$ were generally higher than $\mathrm{Ni}$ and $\mathrm{Cu}$. This is in agreement of many reported for medicinal herbs. Zhu, et al. (2013) [14] reported that the order of the levels of metals in the herb flowers was found to be as $\mathrm{Fe}$ $>\mathrm{Zn}>\mathrm{Cu}>\mathrm{Ni}$. There sults showed that these herbal flowers contained high concentrations of $\mathrm{Fe}$ and $\mathrm{Zn}$. Based on 42 Chinese Herbal Medicinal plants, Wong, et al. (1993) [24] reported that the concentrations $(\mathrm{mg} / \mathrm{kg} \mathrm{dw})$ of these plants were $1.50-26.0$ for $\mathrm{Cu}, 28-1516$ for $\mathrm{Fe},<0.05$ 7.20 for $\mathrm{Ni}$, and $3.80-595$ for $\mathrm{Zn}$. They that $\mathrm{Fe}$ and $\mathrm{Zn}$ were generally present in higher concentrations than the other heavy metals. These are essential metals for plants. The other essential metals for plants, $\mathrm{Cu}$ and $\mathrm{Ni}$ were present in lower concentrations.

The higher metal levels found in some TCHM products were probably from contamination during the drying and preservation steps [24]. Unless consumed in large quantity continuously, at the levels present in the herbal plants, they are unlikely to cause any adverse health effects.
In the present study, there is one TCHM product that used rhizome cymbopogon as parts of ingredients namely Soo Hup Wan Tiny Pills. The mean metal levels $(\mathrm{mg} / \mathrm{kg}$ $\mathrm{dw}$ ) of this product were 8.68 for $\mathrm{Cu}, 1115$ for $\mathrm{Fe}, 8.89$ for $\mathrm{Ni}$ and 35.6 for Zn. Nkansah et al. (2016) [11] reported Cymbopogon citratus (Lemom grass) from Ghana as 2.51 $\mathrm{mg} / \mathrm{kg} \mathrm{dw}$ for $\mathrm{Fe}$ and $0.86 \mathrm{mg} / \mathrm{kg} \mathrm{dw}$ for $\mathrm{Zn}$. This comparison shows that the Fe and $\mathrm{Zn}$ were not highly accumulated in Cymbopogon. Therefore, the high levels of $\mathrm{Fe}$ and $\mathrm{Zn}$ found in Soo Hup Wan Tiny Pills could be possibly not attributable to the ingredient of Cymbopogon.

In the present study, there is one TCHM product that used Artemisia as parts of ingredients namely Biau Leng San. The mean metal levels $(\mathrm{mg} / \mathrm{kg} \mathrm{dw})$ of this product were 22.2 for $\mathrm{Cu}, 1026$ for $\mathrm{Fe}, 12.9$ for $\mathrm{Ni}$ and 61.2 for $\mathrm{Zn}$. Wong et al. (1993) [24] reported that the whole metal levels $(\mathrm{mg} / \mathrm{kg} \mathrm{dw})$ in the plant of Artemisia sp. were 10.0 for $\mathrm{Cu}, 618$ for $\mathrm{Fe}, 2.30$ for $\mathrm{Ni}$ and 30.0 for $\mathrm{Zn}$. The metal levels (mg/kg dry weight) in the leaves of Artemisia nilagirica from India were reported as 23.2 for $\mathrm{Cu}, 820.4$ for $\mathrm{Fe}, 0.30$ for $\mathrm{Ni}$ and 33.7 for $\mathrm{Zn}$ [25]. This comparison shows that the levels of $\mathrm{Cu}, \mathrm{Fe}$ and $\mathrm{Zn}$ found in could be highly accumulated in Artemisia. Therefore, the high levels of $\mathrm{Cu}, \mathrm{Fe}$ and $\mathrm{Zn}$ found in Biau Leng San could possibly be attributable to the ingredient of Artemisia.

In the present study, there are three types of TCHM products that used Mentha herbs as parts of ingredients namely Oh Ouh Pau Chee San Medicated Powder, Stomachache Powder and Herbal Tea Leaves. Their metal ranges were 5.21-12.2 for $\mathrm{Cu}, 189-660$ for $\mathrm{Fe}, 1.87-23.6$ for $\mathrm{Ni}$ and 21.1-78.1 for $\mathrm{Zn}$. The metal levels $(\mathrm{mg} / \mathrm{kg}$ dry weight) in the leaves of Mentha piperitae from India were reported as 0.10 for $\mathrm{Cu}, 3.71$ for $\mathrm{Fe}, 1.01$ for $\mathrm{Ni}$ and 0.10 for $\mathrm{Zn}[26]$.This comparison shows that the $\mathrm{Cu}, \mathrm{Fe}, \mathrm{Ni}$ and Zn were not highly accumulated in Mentha. Therefore, the high levels of the four metals found in the three types of TCHM products could be possibly not attributable to the ingredient of mentha herbs

From a review by Sarma, et al. (2011) [8] on accumulation of heavy metals in selected medicinal plants, they concluded that 1) medicinal plants are prone to contamination from heavy metals, b) authorities should establish a more standardized and universally accepted value for safe levels of heavy metal contents in medicinal plants, and c) steps should be taken to prevent collection and marketing of such medicinal plants that are prone to heavy metal accumulations. Perhaps, steps no. 2 and 3 
should be given emphasized and they can be recommended based on the present study.

\section{Conclusion}

Based on samples collected from selected shops in Peninsular Malaysia, the levels of $\mathrm{Cu}, \mathrm{Fe}, \mathrm{Ni}$ and $\mathrm{Zn}$ in the TCHM samples were comparable to reported studies of TCHM products in the literature. The levels of essential Fe and $\mathrm{Zn}$ were found to be higher than the levels of the essential $\mathrm{Ni}$ and $\mathrm{Cu}$. The present levels of the 20 TCHM products from Malaysia can serve as important baseline information for future reference in the establishment of MRLs of the four less common heavy metals in Malaysia as well as in this region. Therefore, it is difficult to conclude whether the TCHM products are safe from contamination of $\mathrm{Cu}, \mathrm{Fe}, \mathrm{Ni}$ and $\mathrm{Zn}$ since the MRLs for $\mathrm{Cu}, \mathrm{Fe}, \mathrm{Ni}$ and $\mathrm{Zn}$ have not been recommended by WHO (2007) [9] . However, we recommend regular monitoring and control of these popular TCHM products in order to safeguard the consumers' heath on the short- and long-term consumption basis.

\section{Acknowledgement}

The authors wish to acknowledge the financial support provided through the Research University Grant Scheme (RUGS), [Vote no.: 91229], by Universiti Putra Malaysia and e-Science Fund [Vote no.: 5450338], by the Ministry of Science, Technology and Innovation, Malaysia. Also, the Sabbatical Leave (from September 2017 to May 2018) granted to CKYap by Universiti Putra Malaysia.

\section{References}

1. Ernst E (2002) Toxic heavy metals and undeclared drugs in Asian herbal medicines. Trends Pharma Sci 23(3): 136-139.

2. Rao MM, Galib KA (2011) Detection of toxic heavy metals and pesticide residue in herbal plants which are commonly used in the herbal formulations. Environ Monit Assess 181(1-4): 267-271.

3. Chan TYK, Chan Jc, Tomlinson B, Critchley AJH (1993) Chinese herbal medicines revisited: A Hong Kong perspective Lancet 342 (8886-8887): 532-1534.

4. Ernst E (1999) Why complementary medicine? Perfusion. Clinical Pharm. Therap 11: 437.
5. Drew AK, Myers SP (1997) Safety issues in herbasl medicine: implications for the health professions. Med J Aust 166(19): 538-541.

6. Wang X, Zhuang Z, Sun D, Hong J (1999) Trace metals in traditional Chinese medicine: a preliminary study using ICP-MS for metal determination and as speciation. Atom Spectrosc 20: 86-91.

7. Yap CK, Cheng WH, Mohd Rihan N, Nulit R, Omar H, et al. (2018) A preliminary screening of $\mathrm{Cd}$ and $\mathrm{Pb}$ concentrations in the some traditional Chinese herbal medicines bought from selected shops in Peninsular Malaysia. American Journal of Toxicology and Research 1(1): 001-004.

8. HD (Herbal drugs) (2008) Monograph 1433. Pharmeuropa 20(2): 3023.

9. Sarma DM, Deka S, Deka H, Saikia, RR (2011) Accumulation of Heavy Metals in Selected Medicinal, Reviews of Environmental Contamination and Toxicology, Reviews of Environmental Contamination and Toxicology 214: 63-86.

10. WHO (World Health Organization) (2007) WHO guidelines for assessing quality of herbal medicines with reference to contaminants and residues 1-105.

11. Nkansah MA, Hayford ST, Borquaye LS, Ephraim JH (2016) Heavy metal contents of some medicinal herbs from Kumasi, Ghana. Cogent Environ Sci 2: 1234660.

12. Dghaim R, Al Khatib S, Rasool H, Ali Khan M (2015) Determination of Heavy Metals Concentration in Traditional Herbs Commonly Consumed in the United Arab Emirates 2015:1-6.

13. Konieczyński P, Wesołowski M, Rafalski P (2007) Total and extractable iron in selected herbs collected from natural areas in Northern Poland. Herba Polonica 55(4): 27-33.

14. Zhu F, Wang X, Fan W, Qu L, Qiao M, et al. (2013) Assessment of potential health risk for arsenic and heavy metals in some herbal flowers and their infusions consumed in China. Environ Monit Assess 185: 3909-3916.

15. Nkuba LL, Mohammed NK (2017) Heavy Metals and Essential Elements in Selected Medicinal Plants 


\section{Food Science and Nutrition Technology}

Commonly Used for Medicine in Tanzania. Chem Sci Int J 19(2): 1-11.

16. Maiga A, Diallo D, Bye R, Paulsen BS (2005) Determination of some toxic and essential metal ions in medicinal and edible plants from Mali. J Agric Food Chem 53(6): 2316-2321.

17. Rathore J S, Mohit U (2013) Investigation of zinc concentration in some medicinal plant leaves. Res J Pharm Sci 2(1): 15-17.

18. Ansari TM, Ikram N, Najam-ul-Haq M, Fayazz I, Fayazz $\mathrm{Q}$ et al. (2004) Essential trace metal (zinc, manganese, copper, iron) levels in plants of medicinal importance. J Biol Sci 4(2): 95-99.

19. Nishi Y (1996) Zinc and growth. J Am College of Nut 15: 340-344.

20. Obi E, Akunyili DN, Ekpo B, Orisakwe OE (2006) Heavy metal hazards of Nigerian herbal remedies. Sci Tot Environ 369: 35-41.

21. Liu C, Qin J, Dou X, Yang M, Sun X (2018) extrinsic harmful residues in Chinese herbal medicines: types, detection, and safety evaluation. Chin. Herbal Med In Press 10(2): 117-136.
22. Ting A, Chow Y, Tan W (2013) Microbial and heavy metal contamination in commonly consumed traditional Chinese herbal medicines. J Trad Chinese Med 33(1): 119-124.

23. Maobe MAG, Gatebe E, Gitu L, Rotich H (2012) Profile of heavy metals in selected medicinal plants used for treatment of diabetes, malaria and pneumonia in Kisii Region, Southwest Kenya. Global J Pharm 6(3): 245251.

24. Wong MK, Tan P, Wee YC (1993) Heavy metals in some Chinese herbal plants. Biol Trace Elem Res 36: 135-142.

25. Singh NKS, Devi CB, Singh TS, Singh NR (2010) Trace elements of some selected medicinal plants of Manipur. Indian J Nat Prod Resour 1(2): 227-231.

26. Narendhiraknnan RT, Subramanian S, Kandaswamy M (2005) Mineral content of some medicinal plants used in the treatment of diabetes mellitus. Biol Trace Elem Res 103(2): 109-115.

27. Williams PL, James RC, Roberts SM (2015) Principles of Toxicology: Environmental and Industrial Applications. New York: John Wiley and Sons Inc 325345. 